\title{
Country Risk Decision-Maker in Applying the Yield Cash- Flow Estimate
}

\author{
Silviu Carstina ${ }^{1}$, Marian Siminica, Daniel Circiumaru, Anca Bandoi
}

\begin{abstract}
:
The research paper finds applicability in evaluating assets of enterprise and has as main objective to illustrate how the country risk is a decision maker to determine appropriate rates underlying cash flow estimate using the yield method. The transition from the theoretical to the practical study is done through a case study in the agro-industrial farm found in Dolj, Romania.

Practical storage capacities starting from the silos owned by it, the market rates charged for each transaction carried during storage in silos and low country risk used in determining a discount rate, we determined the level of cash-potential flow could be obtained.
\end{abstract}

Key Words: country risk, yield method, cash-flow

Jel Classification: E3, E4, G1

\footnotetext{
${ }^{1}$ University of Craiova, Faculty of Economics and Business Administration, Romania, Craiova, street A.I. Cuza, No. 13, adress e-mail: silviu.carstina@yahoo.com
} 


\section{Introduction}

The overall objective of this paper is to highlight how risk at country level can influence the valuation of assets arising from an undertaking. The overall objective of the work results and other specific targets following the test optimization for determining the factors related to the estimate as accurate as the discount rate used and applied to the cash-flow result, estimated ajutroul emtodei assessment by revenue. Risk is one of the most influential factors common in most sectors of industry-specific economic and decision-makers of the assessor as a result of the estimate of property values.

To demonstrate how risk affects a country by the discount rate we used the fixed assets of a specific agro-industrial company in Romania, Dolj County. Permanently we reported on potential revenue undertaking that would gain as a result of exploitation of those assets under heritage.

The method used is an asset valuation method by revenue and the principle underlying the evaluation is going under concern. The paper is structured in three parts; the first part is in the Terms of specialty use, the focus here is on the opinions of experts in economics, the second one where we presented the research methodology of work, and the last part of Tercera work has as objective to study the theoretical to the practical level, having as reference element to agro-industrial company in Romania, Dolj County.

The reference time or rather the culmination of the paper is estimating the discount rate, which is seen by our example as equivalent to the cost of equity. Based on the CAPM we determined the discount rate being careful to refer to the risk-free base rate at the moment of the market and the market risk premium. To determine the risk premium we turned to studies conducted by the experts addressed the Duff \& Phelps survey conducted in 2013, A Damodaran - "Country default spread and risk premium" in 2014. The research paper ends with the main conclusions drawn from the case study as they are proposed to the company.

\section{Concepts and terms used}

Risk is defined by most authors as the likelihood of an undesirable phenomenon and from which any business will have to bear some losses (Thalassinos et al., 2012; Suryanto, 2014; Thalassinos, 2014; Hanias et al., 2007). An opinion regarding the risk is found in Szatmary (2003), as it defines risk as "the probability that lead to undesirable phenomena in the business of an phenomenon whose result is the loss of material, financial" 2 .

\footnotetext{
${ }^{2}$ Szathmary-Miclea C., Evaluarea și gestionarea riscurilor în întreprinderile mici și mijlocii, Ed. Universității de Vest, Timișoara, 2003
} 
Another view of the risk is presented in a work made by Anghel (2002). He defines the terms of risk as consisting of: an economic failure, a technical failure of the company and because of insolvency. The economic failure is defined as: "the situation when revenues do not cover the total cost of an enterprise" and failure of the firm "the situation where the undertaking ceases activity, generating a loss to creditors" 3 .

Depending on the nature of the enterprise, risks are classified into two main groups: operational risks and financial risks (Thalassinos et al., 2006). Most expressing bleak situation at the company to the risk of bankruptcy. These risks are elements of risk components macroeconomic recognized as the country risk especially in the banking sector (Thalassinos et al., 2013; Thalassinos et al., 2015).

Irina Isac-Maniu defines country risk in her "risk measurement and statistical analysis in Romania" as "the probability of financial losses in the affairs International, losses on certain macroeconomic events and / or policy of the country considered" 4 .

Another concept found in a case study methodology is base rate without risk, which is defined by experts in the field as "the investment that determines the remuneration of invested capital under conditions of minimal risk (interest current on long-term bonds in the euro area - the valuation date) ${ }^{\prime 5}$.

\section{Research metodology}

One of the basic principles in evaluating entities aimed at making a profit is a on going concern. Based on this principle and given the economic and financial situation in business valuation assessor can estimate the evolution of both indicators of profitability and cash flow of the company.

For example let's consider the storage room of a farm agribusiness from Dolj county Territory. For this type of property potential investors (buyers) profiting from the operation of the silo, providing storage services to third parties. In these conditions the value will be determined by the financial flows discounted method.

Given the type of property being valued, it appears that those methods are recommended in such cases (Thalassinos, Liapis 2013). The evaluation method by discounting financial flows is based on capacity availability property (silo) to

\footnotetext{
${ }^{3}$ Anghel. I, Falimentul - radiografie și predicție, Ed. Economică, București, 2002, p. 26

${ }^{4}$ Isaic-Maniu Irina, Măsurarea și analiza statistică a riscului în România, suport de curs descărcat de la adresa: http://www.bibliotecadigitala.ase.ro/biblioteca/carte2.asp?id=206\&idb $=$

${ }^{5}$ Stan Sorin, Anghel Ion, Evaluarea întreprinderii, ed. a 6-a revizuită, Ed. IROVAL, București, 2014
} 
generate positive flows of availability which ultimately remain available to the owner.

For estimating method of updating unfettered financial flows took into account the following assumptions:

- provide permanent capital comes from equity ownership (capital owners) and credit financing;

- $\quad$ in estimating the starting point was the determination of net financial flows that remain to owners;

Arguments supporting its implementation are:

- business viability and ability to generate operating profit in the coming period in a foreseeable future;

- business continuity.

The prerequisites for the application of the method are:

- defining normal operating conditions and running on trends extracted from market analysis and information from the client;

- $\quad$ indicators were expressed in a nominal currency - lei - at an exchange rate of 4.5224 lei / 1 euro.

The method shall apply subject to the information and estimates certainty, namely:

- $\quad$ estimates of the evolution of agriculture in the coming period;

- the average net profitability of the performed activity and the industry;

Application methods requires the following steps:

- $\quad$ estimate the discount rate;

- $\quad$ establish the forecast period;

- $\quad$ estimate the residual value;

- determinate the financial flows to availability.

One of the taught elements used in estimating the cash-flow generating revenue at company level is the discount rate. In order to update financial net cash flows we have to estimate the real discount rate. However since the discount rate or, the cost of equity is not directly observable, various models have been developed, with assumptions and approximations that lead to the appropriate value.

Thus the way is now enshrined by using the CAPM (Capital Assets Pricing Model). The calculation formula is:

where, $\mathrm{R}_{\mathrm{a}}$ - actualization rate

$$
\mathrm{R}_{\mathrm{a}}=\mathrm{R}_{\mathrm{f}}+\left(\mathrm{R}_{\mathrm{m}}-\mathrm{R}_{\mathrm{f}}\right) \times \beta
$$

$\mathrm{R}_{\mathrm{f}}-$ risk-free base rate

$\left(\mathrm{R}_{\mathrm{m}}-\mathrm{R}_{\mathrm{f}}\right)$ - market risk premium

$\beta$ - systematic risk factor assessment 
Applying this approach rigorously in Romania is difficult due to insufficient or no public information on the principal components estimation. Therefore we refer in particular to the risk premium and coefficient $\beta$.

Then we estimate each of the 4 components of the discount rate. To estimate the risk-free basic rate (f) we have to consider the yield to maturity of bonds issued by the US (AAA rating) with 10 years maturity (the yield on the valuation date was $3.10 \%$ ) as the first draft approximation to risk-free rate. In addition we have to consider the yield to maturity of government bonds issued in the Euro zone, with 10 years maturity also (the yield on the valuation date was $2.25 \%$ ) as the latter. These yields refers to a low inflation rate for the euro area while we have to mention that the US inflation rate is missing because the forecast for 2013 the forecasts were made in lei.

In another stage is a quite important model if we estimate the market risk premium. To estimate the market risk premium we have to calculate:

- the market risk premium for a mature market: the risk premium (erp) for a mature market estimated for 2013 according to Duff \& Phelps study is $5.50 \%$;

- the risk premium for a mature market added risk premium of the country of Romania: romania's country risk $(3.60 \%)$ over the material a Damodaran "country default spread and risk premium".

The beta $(\beta)$ coefficient as a necessary factor in determining the discount rate was the next priority in our research. For its estimation we used a single source to estimate the coefficient $\beta$ : $\beta$ coefficient estimation was performed using the database analyzed Reutes's Date for this sector coming out to be 0.36 .

After determining the coefficient $\alpha$ we calculate the $\beta$ coefficient. Additional cost of equity given the CAPM classic was estimated a risk premium $\alpha 0.5 \%$ lower limit values commonly used being $(0 \%-5 \%)$, to competition from competitors and uncertainties related the economic environment in Romania and therefore the purchasing power of customers.

The last stage of the estimation procedure consists in the cost of equity and the presentation of several variations on its determination, the values obtained are presented within.

The cost of equity was estimated for each of the two variants of the basic rate without risk determined above, as follows:

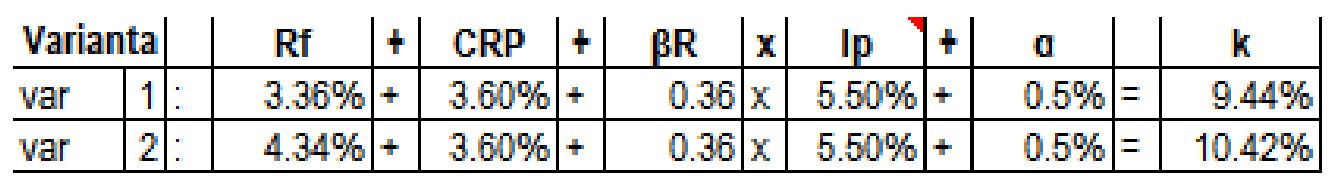


According to the analysis presented above, the cost of equity is in the range of $9.44 \%$ and $10.42 \%$. Given the narrow range in which is reflected the cost of equity we opted for the maximum range is $(10.42 \%)$.

To estimate the weighted average cost of capital other elements considered were:

- cost of capital raised was estimated at 9.19\% (extracted from the site www.bnr.ro on loans over 1 million lei equivalent variant of new loans);

- total debt / invested capital was extracted from the database reuters: $41 \%$.

The resulting value weighted average cost of capital (WACC) is:

\begin{tabular}{lr} 
ccpr = ROE & $10,42 \%$ \\
E / (D+E) & $70,90 \%$ \\
rd & $9,19 \%$ \\
D / (D+E) & $29,10 \%$ \\
imp / p & $16,00 \%$ \\
\hline wacc & $9,63 \%$ \\
\hline
\end{tabular}

Updating financial flows and residual value - there has been correcting financial flows and terminal value discount rate previously estimated. Another problem was to establish the forecast period. Choosing explicit forecast period of 5 years has developed scenarios to consider the following:

- place on the market of services provided by the silo will not change radically, due to factors such as silo site and to mature the business;

- previsions was built on data obtained from the customer and taking into account the data collected on the relevant market.

This limited period of 5 years following the forecast value for the period of default forecast to be contained in the residual value. The residual value, which represents the business after the explicit forecast period is estimated by capitalizing cash-flow at the end of the projection period.

The capitalization rate was estimated based on the discount rate (a) by deducting annual growth rate $(\mathrm{g})$. Use an annual growth rate after the explicit forecast horizon of $2 \%$ (an average increase of the years stipulated extracted from the website of the National Commission for Prognosis).

The final part of the study was to determine the value of financial flows. To build scenarios for the development in 5 years forecast were explicitly considered the following general assumptions:

- 06.11.2013. in this case expresses a trend developments reported at a nominal currency, ie the purchasing power of the lion that date;

- they were taken from market information, data on the activity rate of return assumptions in this scenario. 


\section{Case study}

Based on the values obtained by applying the methodology outlined above and taking into account a number of elements constituting the silo and the income and expenditure relating specifically we achieved an estimate of cash flow, updated discount rate influenced his determination country risk. Thus starting from the annual capacity of 48,200 ton storage silo (on wheat) and taking into account the operations they can perform silo we estimate revenues with it. Of specific silo operations include:

- reception: reception grain hopper;

- condition (tare): separation of foreign bodies;

- drying: drying of the product if it is too wet;

- storage: storage in silo cells during the contract;

- aeration: if the temperature is too high in cells / or the transition from warm in the cold season (and vice versa), goods are transferred to aerated cells;

- gassing: products that are more than 8 months when pests appear, apply gassing substances;

- circulation: moving grain from one cell to another when conducting aeration / gassing;

- delivery: removal of grain and loading cells in cars and / or trucks.

Revenues are expected to be produced annually from storage services are calculated based on storage capacity utilization and the expected average price on each operation envisaged.

Prices were estimated taking into account market survey carried out and the information and estimates received from the client.

The starting point is an estimate of revenue silo storage capacity and occupancy thereof. According to information received from the customer and the market analysis showed that in the Romanian Plain levels of employment are higher since many farmers who work the land (the largest agricultural area of the country) but also due to the limited number of silos offering storage services to third parties. Thus occupancy silo was considered $80 \%$ in the first year of anticipation and foresight reached last year, which coincides with the maturity of the business, at $90 \%$.

In addition to the storage capacity of the silo an important contribution they have and the number of operations performed and their price. Prices are average market rates extracted from market analysis. To estimate the annual income of the silo were built two lines of business:

- storage;

- $\quad$ storage related operations. 
Storage are charged monthly based on the amount of stored grain: According to information gathered from customers and the market, the average load current silo 9 months in the first 2 years and 10 months forecast for the remainder of the forecast Operations related to storage: The rate is applied to each particular job. According to the information obtained from operators market silo, the above operations (except for storage) occurs on average between 1.7 and 2 times a year. This means that in the course of a year may be received and delivered for example, quantities of cereals to 2 times greater than the capacity of the silo. This applies to all transactions that may be performed silage.

Reception and delivery operations is achieved obvious each time, and the operation of aeration and circulation according to data extracted from the market and the customer is likely to carry more than 1 transaction for the same amount of grain. Prudential was considered one operation.

If the drying is important to do the following: tariffs applied by operators for the operation are valid for $1 \%$ moisture / ton. From information supplied by operators moisture content of the wheat harvest is about $17 \%$ and corn by about $25 \%$. For grain storage should be brought to a moisture content of $15 \%$. Therefore we considered an average of $4 \%$ moisture drying each received and delivered quantity.

As for conditioning the operation of the drying rates required relates to $1 \%$ of impurities / tonne. According to information obtained from operators of silos for wheat and maize percentage of impurities is $2 \%$ approximations if sunflowers and percentages may reach $5 \%$. It was envisaged taking into account the purpose of evaluating an average of $3 \%$ impurity.

The revenue estimate was considered an average of 1.5 transactions per year, increasing the forecast period (by increasing the quantity stored and the number of operations increases as more and more storage cycles is achieved during the same months the same storage capacity - multiple inputs and outputs in the capacity limit). Prices used in panel revenues were estimated based on the information presented and market analysis are:

\begin{tabular}{|l|r|}
\hline tariff & euro/ton \\
\hline reception & 2 \\
\hline conditioning & 2 \\
\hline drying & 2,3 \\
\hline storage & 2 \\
\hline aeration & 2 \\
\hline recirculation & 0 \\
\hline delivery & 2 \\
\hline gassing & 2 \\
\hline
\end{tabular}


Revenues from specific storage operations were estimated at 3,335,089 lei in 1 previzune and reach 3,923,634 lei in May forecast. Income from operations (delivery / reception, conditioning, gassing, aeration) were estimated at 6,447,839 lei in the first year and reaching 8,192,548 lei forecast in May forecast.

Operating expenses were extracted from the silo of customer history, but also from information gathered from other operators silos. According to information collected gross profit margin for such services is approx. $25 \%$ of total turnover. This margin was recovered by consulting the database and Reuters, for companies carrying out similar activities.

Depreciation was correlated with the level of investment. Given the age of the building, we considered the annual investments needed at annual depreciation.

The income and expenses is presented below:

Tabel 4.23 - Previziunea indicatorilor de rentabilitate

\begin{tabular}{|c|c|c|c|c|c|c|c|}
\hline \multirow[b]{2}{*}{ Year } & \multicolumn{7}{|c|}{ Previsions } \\
\hline & & 2013 & An1 & An2 & An3 & An4 & An5 \\
\hline $\begin{array}{l}\text { Storage } \\
\text { capacity } \\
\text { (ton) }\end{array}$ & & 48200 & 48200 & 48200 & 48200 & 48200 & 48200 \\
\hline $\begin{array}{l}\text { Degree of } \\
\text { utilization }\end{array}$ & & & $85 \%$ & $87 \%$ & $88 \%$ & $89 \%$ & $90 \%$ \\
\hline & & & & & & & \\
\hline Tariff & $\begin{array}{l}\text { Euro } \\
\text { /ton }\end{array}$ & & lei/ton & lei/ton & lei/ton & lei/ton & lei/ton \\
\hline reception & 2 & & 9,04 & 9,04 & 9,04 & 9,04 & 9,04 \\
\hline conditioning & 2 & & 9,04 & 9,04 & 9,04 & 9,04 & 9,04 \\
\hline drying & 2,3 & & 10,4 & 10,4 & 10,4 & 10,4 & 10,4 \\
\hline storage & 2 & & 9,04 & 9,04 & 9,04 & 9,04 & 9,04 \\
\hline aeration & 2 & & 9,04 & 9,04 & 9,04 & 9,04 & 9,04 \\
\hline recirculation & 0 & & 0 & 0 & 0 & 0 & 0 \\
\hline delivery & 2 & & 9,04 & 9,04 & 9,04 & 9,04 & 9,04 \\
\hline gassing & 2 & & 9,04 & 9,04 & 9,04 & 9,04 & 9,04 \\
\hline $\begin{array}{l}\text { Price } \\
\text { medium/ton }\end{array}$ & & & 64,67 & 64,67 & 64,67 & 64,67 & 64,67 \\
\hline $\begin{array}{l}\text { No. } \\
\text { Operations }\end{array}$ & & & 1,5 & 1,6 & 1,7 & 1,7 & 1,8 \\
\hline $\begin{array}{l}\text { Revenue } \\
\text { operation }\end{array}$ & & & 6.447 .839 & 7.039 .523 & 7.565 .464 & 7.651 .436 & 8.192 .548 \\
\hline $\begin{array}{l}\text { No. Month } \\
\text { storage }\end{array}$ & & & 9 & 9 & 10 & 10 & 10 \\
\hline $\begin{array}{l}\text { Revenue } \\
\text { storage }\end{array}$ & & & 3.335 .089 & 3.413 .562 & 3.836 .442 & 3.880 .038 & 3.923 .634 \\
\hline & & & & & & & \\
\hline
\end{tabular}




\begin{tabular}{|c|c|c|c|c|c|c|}
\hline $\mathrm{CA}$ & 8.315 .489 & 9.872 .928 & 10.453 .085 & 11.401 .907 & 11.531 .474 & 12.116 .183 \\
\hline $\begin{array}{l}\text { EBITDA } \\
\text { margin }\end{array}$ & & $25 \%$ & $25 \%$ & $25 \%$ & $25 \%$ & $25 \%$ \\
\hline EBITDA & & 2.445 .732 & 2.613 .271 & 2.850 .477 & 2.882 .868 & 3.029 .046 \\
\hline Amortization & & 470.785 & 470.785 & 470.785 & 470.785 & 470.785 \\
\hline EBIT & & 1.974 .947 & 2.142 .486 & 2.379 .692 & 2.412 .084 & 2.558 .261 \\
\hline Tax & & 315.992 & 342.798 & 380.751 & 385.933 & 409.322 \\
\hline Net profit & & 1.658 .956 & 1.799 .688 & 1.998 .941 & 2.026 .150 & 2.148 .939 \\
\hline Net flows & & 2.129 .740 & 2.270 .473 & 2.469 .726 & 2.496 .935 & 2.619 .724 \\
\hline
\end{tabular}

Source: Tabel obținut în excel

Given the results obtained with the yield method for undertaking agro taken as an example, we demonstrated how the profitability of the company may be influenced by them. Also based on this method and applying the going concern assumption we could make a forecast of profitability and cash-flow company on the assumption that profitability and cash-flow must coexist for the enterprise assuring its longevity.

\section{Conclusions}

The evaluation method that is based on potential revenue derived by an enterprise proved to be not only one with a degree of subjectivity high valuation is by its specific charge of bias, but also a method that shows a higher high sensitivity to oscillations and the instability of the economic environment of a country, region, county, etc.

The risk as perceived by most experts in the economy both nationally and internationally plays an important role in predicting and forecasting especially cashflows derived by an enterprise.

Both theory and practice have shown us that the risk is how small it affects in one way or another within an enterprise results especially in terms of management decisions.

Country risk is an important factor in overall investment environment for monetary policy of a country, how we determined the discount rate used to determine money while proving once again that.

Studies conducted at the country and not only demonstrated and continues to demonstrate today the role that risk plays in the country regardless of economic decision-making process to which we refer. Although economic theory presented direct proportionality between risk and profit at the country situation turns out to be mostly backwards. So in countries considered tax havens risk is small compared with the profit and in countries such as Romania developing risk often proved to be a higher level of profit. 


\section{References}

Anghel. I, Falimentul - radiografie și predicție, Ed. Economică, București, (2002).

Antonio Partal Urena, Fernando Moreno Bonilla, Manuel Cano Rodriguez şi Pilar Gomez Fernandez-Aguado, (2012). Direccion financiera de la empresa, Ediciones Piramide, Madrid.

Hanias, M. P., Curtis, G. and Thalassinos, J. E. (2007). Non-linear dynamics and chaos: The case of the price indicator at the Athens Stock Exchange. International Research Journal of Finance and Economics, 11, 154-63.

Isaic-Maniu Irina, Măsurarea și analiza statistică a riscului în România, suport de curs descărcat de la adresa: http://www.bibliotecadigitala.ase.ro/biblioteca/carte2.asp?id=206\&idb $=$

Maxim Emil, (2010). Diagnosticarea și evaluarea Organizaţiilor, Ed. SEDCOM Libris, Iaşi.

Nicolae, V., (coordonator), Dumitrache CARACOTA, Daniela Luminita CONSTANTIN, Cornelia PARLOG, Ilie GRADINARU, Vasilica SLAVESCU, Valerian TOBULTOC, Previziune Macroeconomică, ASE, București, suport de curs în format electronic, extras de pe link-ul http://www.bibliotecadigitala.ase.ro/biblioteca/carte2.asp?id=71\&idb=11

Stan Sorin, Anghel Ion, (2014). Evaluarea întreprinderii, ed. a 6-a revizuită, Ed. IROVAL, București.

Szathmary-Miclea C., (2003). Evaluarea și gestionarea riscurilor în întreprinderile mici și mijlocii, Ed. Universităţii de Vest, Timişoara.

Suryanto, T. (2014). Determinants of Audit Fee Based on Client Attribute, Auditor Attribute, and Engagement Attribute to Control Risks and Prevent Fraud: A Study on Public Accounting Firms in Sumatra-Indonesia. International Journal in Economics and Business Administration, Volume II, Issue 3, 27-39.

Thalassinos, I.E. and Liapis, K. (2013). A Comparative Analysis for the Accounting Reporting of Employee Benefits between IFRS and other Accounting Standards: A Case Study for the Biggest Listed Entities in Greece. International Journal of Economics and Business Administration, 1(1), 99-124.

Thalassinos, I.E., Maditinos, D. and Paschalidis, A. (2012). Observing evidence of insider trading in the Athens Stock Exchange. Journal of Economic Structures, 1(1), 1.

Thalassinos, I.E. Kyriazidis Th., Thalassinos E.J. (2006). The Greek Capital Market: Caught in Between Corporate Governance and Market Inefficiency. European Research Studies Journal, 9(1-2), 3-24.

Thalassinos, I.E., Venediktova, B., Staneva-Petkova, D. (2013). Way of Banking Development Abroad: Branches or Subsidiaries. International Journal of Economics and Business Administration, 1(3), 69-78.

Thalassinos, E.P. (2014). Credit Default Swaps and Sovereign Debt in Eurozone. $\underline{\text { Chapter }}$ book in, Risk Management: Strategies for Economic Development and Challenges in the Financial System,(eds), D. Milos Sprcic, Nova Publishers, ISBN, 978-1.

Thalassinos, I.E., Th. Stamatopoulos, D.T. and Thalassinos, E.P. (2015). The European Sovereign Debt Crisis and the Role of Credit Swaps. Chapter book in The WSPC Handbook of Futures Markets (eds) W. T. Ziemba and A.G. Malliaris, in memory of Late Milton Miller (Nobel 1990) World Scientific Handbook in Financial Economic Series Vol. 5, Chapter 20. 